\title{
Physiochemical Characterization and Potential of Synthesis Gas Production from Rubber Wood Biomass by Using Downdraft Gasifier
}

\author{
Syed Haseeb Sultan ${ }^{1}$, Arkom Palamanit ${ }^{2}$, Kua-Anan Techato ${ }^{3}$, Muhammad Amin ${ }^{4}$, \\ Khurshid Ahmed Baloch ${ }^{5}$
}

RECEIVED ON 13.11.2019, ACCEPTED ON 19.05.2020

\begin{abstract}
Bioenergy has gained great interest in the recent years for being environmentally friendly and renewable energy resource. Southern Thailand is well-known for agro-industry including rubber tree plantations and processing, which provide biomass that could be applied to produce bioenergy. Thus, this study aimed to investigate the energy potential of Rubber Wood Chips (RWC), Rubber Wood Pellets (RWP), Unburned Char (UBC) from rubber wood, blended RWC:UBC (50:50\%) and blended RWP:UBC (50:50\%). The physiochemical properties including bulk density, proximate composition, ultimate composition, heating value, Thermogravimetric Analysis (TGA), and lignocellulose content were determined for the biomass samples. The thermochemical conversion of biomass to syngas was performed using a downdraft gasifier operated at equivalence ratio 0.3. The results showed that the biomass was rich in carbon (content ranging from 44.77 to $\mathbf{5 8 . 5 4 \% ) ~ m a k i n g ~ i t ~ s u i t a b l e ~ f o r ~ u s e ~ a s ~ a ~ s o l i d ~ f u e l ~ f o r ~ g a s i f i c a t i o n ~ o r ~ c o m b u s t i o n . ~ T h e ~ m o i s t u r e ~ c o n t e n t s ~ o f ~ t h e ~}$ biomass samples were below 10\%. The contents of volatile matter in RWC and RWP were 74.40 and $75.40 \%$, respectively. The UBC had a high fixed carbon content $\mathbf{( 5 0 . 6 0 \% )}$ ) and comparatively low volatile matter (19\%). The bulk densities of RWC, RWP and UBC were 193, 555 and $177\left(\mathrm{~kg} / \mathrm{m}^{3}\right)$, respectively. The TGA showed the maximum weight loss of RWC and RWP around $400{ }^{\circ} \mathrm{C}$, but this was at $800{ }^{\circ} \mathrm{C}$ for UBC. The higher heating values of RWC, RWP and UBC were $17.8 \mathrm{MJ} / \mathrm{kg}, 17.4 \mathrm{MJ} / \mathrm{kg}$ and $19.3 \mathrm{MJ} / \mathrm{kg}$, respectively. The $\mathrm{RWC}$ and RWP had high cellulose and hemicellulose contents while UBC was rich in lignin. The syngas obtained from any of these biomass samples was mainly $\mathrm{CO}(10.81-22.67 \%)$ and $\mathrm{CH}_{4}(\mathbf{0 . 0 6 - 3 . 1 6 \%})$ with the lower heating value ranging from 2.78 to $4.72 \mathrm{MJ} / \mathrm{Nm}^{3}$. These results indicate that rubber wood biomass in various forms has relatively high potential for bioenergy applications via gasification, and it can help to support the renewable energy sector in Thailand.
\end{abstract}

Keywords: Biomass, Biomass characterization, Gasification, Renewable energy, Rubber wood biomass, Syngas production

1 Sustainable Energy Management Program, Faculty of Environmental Management, Prince of Songkla University, Hat Yai, Songkhla, 90110, Thailand. Email: haseebsultan9@gmail.com

2 Interdisciplinary Graduate School of Energy Systems, Prince of Songkla University, Hat Yai, Songkhla, 90110, Thailand. Email: arkom.p@psu.ac.th (Corresponding Author)

${ }^{3}$ Environmental Assessment and Technology for Hazardous Waste Management Research Center, Faculty of Environmental Management, Prince of Songkla University, Hat Yai, Songkhla, Thailand.

Emailuhugua@hotmail.com

${ }^{4}$ Department of Chemical Engineering, Faculty of Engineering, BUITEMS, Quetta, Pakistan. Email: engr_amin63@yahoo.com

5 Molecular Biotechnology Laboratory, Department of Industrial Biotechnology, Faculty of Agro-Industry, Prince of Songkla University, Songkhla, Thailand. Email: khurshidbaloch555@gmail.com

This is an open access article published by Mehran University of Engineering and Technology, Jamshoro under CC BY 4.0 International License. 


\section{INTRODUCTION}

I n energy context the world is facing two main challenges, namely emissions of lethal gases into the environment and potential fossil fuel depletion due to excessive consumption $[1,2]$. The consumption of fossil fuels releases extra carbon dioxide $\left(\mathrm{CO}_{2}\right)$ to the environment, increasing proportion of this gas in the atmosphere. The British Petroleum (BP) statistical review of world energy reported an increase in $\mathrm{CO}_{2}$ emissions from 29,714.2 million tons in 2009 to 33,444.0 million tons in 2017 [3]. Moreover, the conversion of organic residues to fossil fuels takes millions of years. As the industrialized civilization searches for immediate and replenishing energy sources, the global energy demand is projected to increase by approximately $28 \%$ from 2015 to 2040 [3]. Such concerns have led the world towards renewable and sustainable energy systems. Renewable energy resources enable sustainable energy and environment. There are various renewable energy resources, including geothermal, hydro, solar, marine, wind and biomass. Bioenergy means energy converted from various types of biomass into for example heat and electricity [1].

Thailand is an energy intensive country in the ASEAN region. Mostly the energy used in Thailand is obtained from fossil fuels, including crude oil, coal and natural gas. The reliance on fossil fuels or fossil energy, particularly in countries that need to import fossil fuels, not only affects energy security and sustainability but also strongly influences economics, society and environment. The emissions of Greenhouse Gases (GHGs) from the utilization of fossil fuels cause global warming and climate change $[3,4]$. Due to these concerns, renewable and alternative energy receive significant interest from many countries worldwide, including Thailand. Therefore, the government of Thailand has a policy to reduce the proportion of fossil fuels in energy consumption by increasing the utilization of Renewable and Alternative energy ( $\mathrm{RE}$ and $\mathrm{AE}$ ), following the Alternative Energy Development Plan 2015 (AEDP 2015). The RE and AE that have high potential in Thailand include solar, wind and biomass [5].
Biomass is a potential renewable energy resource originated from forests, plants, trees, crops, animal waste, and human waste. Biomass stores solar energy as chemical energy captured in photosynthesis [6]. Normally, the agro-industrial wastes and residues are mainly lignocellulosic biomass. The abundance and incorrect management of the agro-industrial wastes and residues are major environmental concerns in the industrial era. The lignocellulosic biomass can be converted into valuable products, mainly bioenergy and bio-chemical products [7].

Being an agro-industrial country, Thailand has great potential for using biomass in energy applications. The replanting, harvesting, and processing of plants, crops and agricultural products provide many residues and wastes. The biomass produced in Thailand includes oil palm biomass, rubber wood biomass, rice husk, cassava stalk, cassava rhizomes, and corn stalk and leaves. Most of these biomasses are suitable for bioenergy applications. The annual biomass potential of Thailand is about 65 Petajoules (PJ) [8]. Among the biomass sources, rubber wood biomass that from rubber trees (Hevea brasiliensis) is among the most economically important biomasses in Thailand, particularly in the southern region. Rubber trees are the main source of natural rubber or latex. The natural rubber manufacturing industry is massive in southern Thailand, which contributed about $37 \%$ of the total global natural rubber production last year [9]. The estimated area of rubber cultivation, according to Thailand Board of Investment (www.boi.go.th), is 3.5 million hectares with a significant 2.7 million hectares in the southern provinces. The southern provinces bound by the Gulf of Thailand from southeast and by Andaman sea from southwest contribute a large share of the rubber manufacturing industries in Thailand. Apart from natural rubber, the rubber industry also produces large quantities of biomass. A standing rubber tree can produce approximately $2.1 \mathrm{~m}^{3}$ of biomass [10]. The biomass streams produced in the cycle of rubber industries include rubber tree roots, stumps, leaves, and rubber wood bark, rubber wood sawdust, and rubber wood chips. This bulk amount of biomass is equivalent to about $1600 \times 10^{6}(\mathrm{kWh} /$ year $)$ of energy [10]. 
The physiochemical properties of biomass are important for its energy content, environment impacts and economic value. Understanding the physiochemical properties of biomass will enable choosing appropriate conversion methods or technologies that produce bioenergy, which is valuable for both economics and environment [11]. Regarding the energy content of biomass, many measures have been taken to associate the Higher Heating Value (HHV) with proximate and ultimate compositions. Over the past two decades, emphasis on renewable solid fuels has led to many empirical correlations based on the data obtained from proximate and ultimate analyses of biomass (agricultural wastes and residues) for predicting the HHV. One of the earliest and most popular correlations is the Dulong correlation [12].

Conversion of biomass into biofuels or bioenergy can be performed by several processes or methods, such as mechanical, biochemical, thermochemical and combined processes [13-15]. The criteria for choosing the biomass conversion processes depend on many factors, such as biomass properties, final fuel or energy forms, utilization target, cost, storage and transportation, as well as the social and environmental impacts [16-18]. Thermochemical conversion processes are conventional processes that are widely used in many sectors for heat and power generation, as well as in liquid or gaseous fuel production. Torrefaction, pyrolysis, gasification and combustion are examples of thermochemical conversion [19]. These processes provide different forms of fuels or energies and operate in mutually different conditions. Gasification processes are designed and applied to generate or convert solid fuels or biomass to synthesis gases or producer gas. This process is operated at an elevated temperature ranging from $700{ }^{\circ} \mathrm{C}$ to $1000{ }^{\circ} \mathrm{C}$ during partial oxidation. The main components in synthesis gases are $\mathrm{CO}, \mathrm{H}_{2}, \mathrm{CH}_{4}$, and lighter gaseous hydrocarbons depending on the process and operating conditions [20]. Besides the gaseous fuels, biomass gasification also produces liquid (tars, oils and other condensates) and solids (char, ash). The fuel gases can be used for heat and power generation in internal combustion engines, combustion chambers, or fuel cells [21]. The gas products can be used to produce methanol by Fischer-Tropsch (FT) process, and to other fuel liquids and chemicals. Gasification of biomass and combustion of fuel gases generate the similar products as direct combustion of solids biomass, but the pollution control and conversion efficiencies may be improved. However, previous studies have shown that the quantity and quality of synthesis gases depends on many factors, such as biomass type, properties and composition, operating conditions and gasifier type. Type, properties and composition of biomass strongly influence the yield and composition of synthesis gases [22-24]. This is because each biomass has different physical and chemical properties such as particle size, density, moisture content, ash content, elemental composition, lignocellulose content, and thermal decomposition behavior.

The objective of this study was therefore to evaluate the energy potential of different rubber wood biomasses for producing synthesis gases in a downdraft gasifier. The rubber wood biomass types used in this study included RWC, RWP, UBC, UBC mixed with RWC, and UBC mixed with RWP. The potential for synthesis gas generation was considered from physicochemical properties of rubber wood biomass, including bulk density, proximate analysis, ultimate analysis, lignocellulose content, TGA, HHV, and the energy equivalence to fossil fuels. The energy contents in synthesis gases were determined by performing the gasification of each biomass with the downdraft gasifier operated at specific conditions.

\section{MATERIALS AND METHODS}

\subsection{Biomass preparation}

The RWC was obtained from a factory that produces rubber wood chips, located at Khlongngae, Sadao District, Songkhla Province, Thailand. The size of RWC was about $20 \times 33 \mathrm{~mm}$. The UBC was char mixed in the bottom ash of a boiler system that used rubber wood biomass as fuel. The UBC was separated from bottom ash by sieving and the size of UBC was about 10-20 mm. The RWP was obtained from wood pellet production factory located at Rattaphum District, Songkhla Province, Thailand. The RWP had $8 \mathrm{~mm}$ diameter and 20-40 $\mathrm{mm}$ length. The prepared biomass samples were dried in a greenhouse dryer until desired moisture content. 


\subsection{Preparation of blended biomass samples}

To enhance the fuel efficiency, the concept of co-firing, co-fuel or blended biomass is of great interest nowadays. Therefore, dried RWC or RWP was blended individually with UBC at 50-50 weight ratio. Then, the blended samples were kept in airtight bags and stored at room temperature prior to the experiment.

\subsection{Determination of biomass properties and product analysis}

\subsubsection{Proximate and ultimate analysis}

The moisture content, volatile matter, fixed carbon content and ash content were determined in proximate analysis by Thermogravimetric analyzer (TGA) technique with Marco TGA 701 (LECO, UK) according to ASTM D7582 procedures. The elemental components, including carbon $(\mathrm{C})$, hydrogen $(\mathrm{H})$, nitrogen $(\mathrm{N})$, sulphur $(\mathrm{S})$ and oxygen $(\mathrm{O})$ content were determined by difference.

\subsubsection{Lignocellulosic composition determination}

The lignocellulosic contents in RWC, RWP and UBC were estimated via three procedures, namely the percentages of cellulose, hemicellulose, and lignin were determined in terms of acid detergent fiber (ADF), Neutral Detergent Fiber (NDF), and Acid Detergent Lignin (ADL) [25].

\subsubsection{Energy content in form of higher heating value}

The actual HHV was determined with a bomb calorimeter (IKA C5000, Germany). The actual HHV was also compared with the predicted HHV. The predicted HHV for the biomass samples was determined by using proximate and ultimate analysis results in Eq. (1-4) below [26 - 28].

$$
\begin{aligned}
\mathrm{HHV}_{1}= & 0.3516 \mathrm{C}+1.16225 \mathrm{H}-0.1109 \mathrm{O}+0.0626 \\
& \mathrm{~N}+0.10465 \mathrm{~S}(\mathrm{MJ} / \mathrm{kg}) \\
\mathrm{HHV}_{2}= & 0.341 \mathrm{C}+1.322 \mathrm{H}-0.12 \mathrm{O}-0.12 \mathrm{~N}+0.0686 \mathrm{~S} \\
& -0.0153 \mathrm{Ash}(\mathrm{MJ} / \mathrm{kg}) \\
\mathrm{HHV}_{3}= & 0.196 \mathrm{FC}+14.119(\mathrm{MJ} / \mathrm{kg}) \\
\mathrm{HHV}_{4}= & 0.0889 \mathrm{~L}+16.8218(\mathrm{MJ} / \mathrm{kg})
\end{aligned}
$$

2.3.4 Thermal decomposition behavior via thermogravimetric analysis

The TGA is the determination of the thermal decomposition behavior of biomass. The determination was performed using a thermogravimetric analyzer (Perkin Elmer, USA), according to ASTM E1131. The program used the temperature range from 50 to $1000{ }^{\circ} \mathrm{C}$, at the heating rate of $10^{\circ} \mathrm{C} / \mathrm{min}$ under nitrogen gas atmosphere.

\subsubsection{Determination of syngas composition}

The syngas sample obtained from gasification of each biomass was continuously collected into a $10 \mathrm{dm}^{3}$ gas sample bag. The composition of syngas was then analyzed using micro gas chromatography with a thermal conductivity detector (Micro GC TCD; Varian CP-4900 model) for measuring $\mathrm{CH}_{4}, \mathrm{CO}, \mathrm{CO}_{2}$ and $\mathrm{H}_{2}$ (Vol., \%). The Lower Heating Value (LHV) of syngas was then estimated using Eq. (5).

LHV $\left(\mathrm{kJ} / \mathrm{m}^{3}\right)=\Sigma$ Vol. \% of gas component $\mathrm{x}$ LHV of gas component

\subsection{Experimental set-up and procedures}

The downdraft gasifier shown in Fig. 1 was used to study syngas production from RWC, RWP, UBC and the blended biomass samples. The reaction chamber of this gasifier has $79 \mathrm{~cm}$ height, $38 \mathrm{~cm}$ inner diameter and $38.7 \mathrm{~cm}$ outer diameter. Air was supplied to the gasifier by a ring blower. The flow rate of the air was measured with a flow meter and the flow rate of air was controlled with a balancing valve. The biomass sample of $12 \mathrm{~kg}$ weight was fed manually into the gasifier via the biomass inlet port. The gasifier was operated for 1.5-2 hours per experiment. This system generates maximum thermal power output of $25 \mathrm{~kW}$. The equivalent ratio of air was maintained at 0.3, which was the best value determined in a preliminary evaluation. In preliminary experiments, the ER was varied between 0.2-0.4 and flame consistency, flame color and gas composition were observed and evaluated. At a low ER the combustion was incomplete and inconsistent flame behavior was observed, while at a high ER the smoke was white indicating an excess of air. However, at ER 0.3 the flame was blue/yellowish in color and consistent, and 
the gas was mainly composed of $\mathrm{CO}$ and $\mathrm{CH}_{4}$. Hence, this condition was chosen for operation in further experiments. The combustion zone had the temperature fluctuating in $700-900{ }^{\circ} \mathrm{C}$. Samples of syngas were collected in gas bags and analyzed by GC for composition.

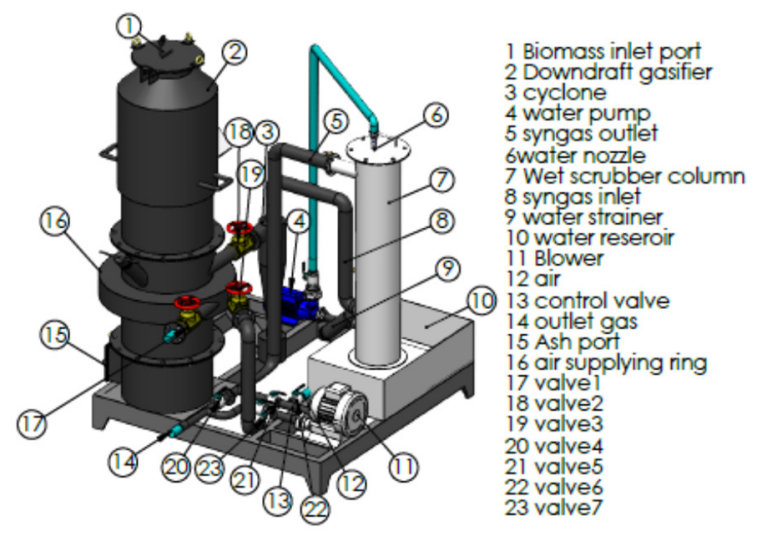

Fig. 1: Downdraft gasifier

\section{RESULTS AND DISCUSSION}

\subsection{Potential for synthesis gases production}

The proximate and ultimate analysis of biomass is necessary to evaluate its composition and potential for applications. Hence, RWC, RWP and UBC were analyzed by standard ASTM procedures and the results are presented in Table 1. It is seen that the moisture contents in all cases were below $10 \%$. Biomass with a low moisture is generally regarded a feasible choice for energy applications via gasification. This is because the low moisture content of biomass enables getting syngas with a low moisture content. Moreover, low moisture in the biomass also improves stability of the temperature in combustion zone, as well as thermal efficiency.

The presence of volatile matter indicates the degree of combustibility of a solid fuel. The volatile matter in RWC and RWP was high enough at $74.40 \%$ and $75.40 \%$, respectively. This indicates high vapor or gas generation capacity and further transformation into gas and liquid products upon the devitalization of biomass [29]. However, the UBC contained less volatile matter (19.0\%) than RWC and RWP. This is because of UBC is char remaining from rubber wood combustion, hence the volatile matter was already released and only a low content remained. The ash content in UBC was higher than in fresh biomass (RWP or RWC), because UBC had already thermally decomposed during combustion in the boiler. Table 1 also presents the elemental compositions of the biomass samples. As can be seen, the carbon contents in all cases ranged within 44.77-58.54\%, which indicates suitability for use as a solid fuel [30]. As can be observed that the hydrogen content of UBC was low due to the thermal decomposition during combustion process, which is consistent with the results of proximate analysis.

Table 1: Composition of RWC, RWP and UBC

\begin{tabular}{|l|c|c|c|}
\hline \multicolumn{1}{|c|}{$\begin{array}{c}\text { Compositional } \\
\text { Analysis }\end{array}$} & \multicolumn{3}{c|}{ Biomass Sample } \\
\hline $\begin{array}{l}\text { Proximate Analysis (\% } \\
\text { weight as received } \\
\text { basis) }\end{array}$ & RWC & RWP & UBC \\
\hline Moisture Content & 6.40 & 7.60 & 8.20 \\
\hline Volatile Matters & 74.40 & 75.40 & 19 \\
\hline Fixed Carbon & 16.80 & 15 & 50.6 \\
\hline Ash Content & 2.40 & 2 & 22.2 \\
\hline Ultimate Analysis (\% weight, as received) \\
\hline C & 45.50 & 44.77 & 58.54 \\
\hline H & 5.84 & 5.66 & 1.19 \\
\hline N & 0.22 & 0.21 & 0.23 \\
\hline S & 0.02 & 0.08 & 0.05 \\
\hline O* & 39.62 & 39.68 & 9.59 \\
\hline
\end{tabular}

* By difference: $\mathrm{O}=100-\mathrm{C}+\mathrm{H}+\mathrm{N}+\mathrm{S}+$ Moisture + Ash [45]

The cellulose and hemicellulose contents in biomass are highly combustible, and these are the volatile matters in the biomass, whereas the lignin makes solid char [31]. The rubber wood biomass with higher cellulose and hemicellulose contents showed more volatile products. RWP had high volatile matter at $75.4 \%$ with cellulose and hemicellulose contents of 60.06 and $15.3 \%$, respectively. The RWC had $74.4 \%$ volatile matter with $17.2 \%$ of hemicellulose and $57.7 \%$ of cellulose (Table 1 and Fig. 2). UBC contained $4.35 \%$ cellulose and $3.9 \%$ hemicellulose giving less volatile matter at $19 \%$ (Table 1 and Figure $2)$. The moisture contents of the biomass feedstocks, namely RWC (6.4\%), RWP (7.6\%), and UBC (8.2\%), are quite suitable for gasification [32]. High fixed carbon contents in these biomass feedstocks indicate good performance in gasification [31]. UBC showed 
the highest fixed carbon at $50.6 \%$, followed by RWC and RWP at $16.8 \%$ and $15 \%$, respectively (Table 1).

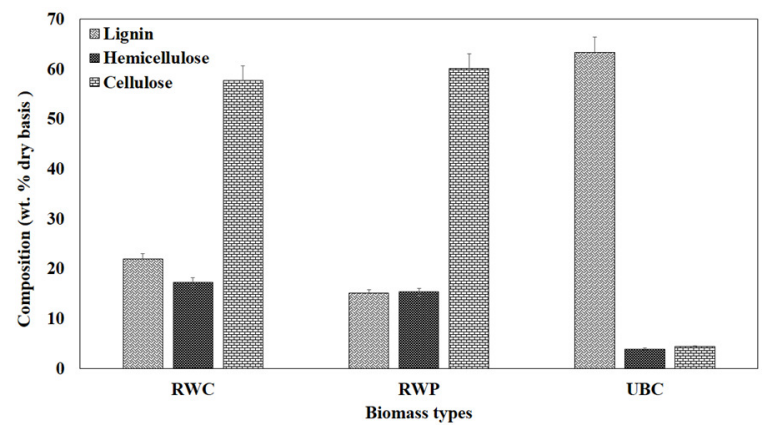

Fig. 2: Compositions of RWC, RWP and UBC

\subsection{Heating values of biomass samples}

Heating value is an important factor in the selection of a suitable biomass for large-scale energy generation by gasification. The measured heating value is more reliable than calculated estimates, on deciding whether a biomass is suitable for gasification or not. Therefore, the energy content of each type of biomass species should be determined to establish their potential for bioenergy applications. Table 2 shows the HHV of RWC, RWP and UBC. The results show that the HHV of RWC, RWP and UBC was 17.8, 17.4 and 19.3 $\mathrm{MJ} / \mathrm{kg}$, respectively. The UBC had the highest HHV due to mostly containing fixed carbon, as shown in the proximate analysis. Normally, biomass comprises organic substances that are mostly carbon, hydrogen, and oxygen, while sulphur and nitrogen contents in the biomass are much lesser. When biomass is completely combusted, it provides thermal energy, flue gases and water vapor [33]. The generated water vapor carries latent heat given off upon condensation. The heating value, which includes the latent heat of condensation, is called the HHV, while when the latent heat is lost (water not condensed) we have the Lower Heating LHV [34]. There are two new empirical correlations based on proximate and ultimate analysis of biomass $[35,36]$, which are commonly used for estimates of HHV. Heating value is the amount of energy generated when a substance undergoes complete combustion. The dry basis measurement of proximate analysis gives the estimated contents of volatile matter, ash, and fixed carbon, while the ultimate analysis shows the detailed elemental composition as regards carbon, hydrogen, oxygen, etc. [34].

\subsubsection{Proximate analysis based higher heating value}

The importance of the biomass composition depends on the method of valorization of a biomass feedstock. Feedstock with a higher organic carbon content can be more suitable as a carbon source for microorganisms or for methanol production, whereas higher volatile matter and fixed carbon contents are more suitable for thermochemical processing, such as gasification [37]. The calorific value of a biomass feedstock is the amount of heat released when the feedstock goes through a complete combustion and the combusting material is cooled down to $24.85^{\circ} \mathrm{C}\left(298^{\circ} \mathrm{K}\right)$. Proximate analysis and ultimate analysis are important factors associated with the expected calorific value of a biomass feedstock.

Estimating heating values for lignocellulosic and carbonaceous materials can be done on dry basis based on the proximate analysis with the correlations by Cordero et al. (2001) [35]. Correlation equations used for energy value predictions are based on multiple linear regression with least squares method. The equations to estimate higher heating values are given below.

$\mathrm{HHV}=354.3 \mathrm{FC}+170.8 \mathrm{VM}$

$\mathrm{VM}+\mathrm{FC}+\mathrm{ASH}=100$

Here HHV represents the higher heating value $(\mathrm{kJ} / \mathrm{kg}$, dry basis), FC represents fixed carbon, and VM represents the volatile matter, respectively, both in weight percent on dry basis. ASH represents the ash content in weight percent on dry basis, and HHV can also be estimated in terms of the measured parameters as follows:

$\mathrm{HHV}=35430-183.5 \mathrm{VM}-354.3 \mathrm{ASH}$

Using Eq. (9), the heating value has been calculated and compared with the experimental heating values. Mean absolute error between predicted and experimental values has been calculated using following equation. 
Mean absolute error $(\mathrm{MAE})=\left(\mathrm{HHV}_{\text {Predicted }}-\right.$

$\left.\mathrm{HHV}_{\text {Experimental }}\right) / \mathrm{HHV}$ Experimental

The measured and estimated heating values for biomass species were compared and found to deviate by $0.04 \%$ to $0.08 \%$, for the proximate analysis given in Table 2, and a graph is shown in Fig. 3. The difference between the measured and the estimated heating values is within the acceptable range 0.5-2 $\mathrm{MJ} / \mathrm{kg}$ for all biomass samples, except for the unburned char biomass fuel (Table 2 and Fig. 3).

Table 2: Comparison of HHV between Measured and Estimates from Proximate Analysis

\begin{tabular}{|c|c|c|c|}
\hline \multirow{2}{*}{ Biomass } & \multicolumn{3}{|c|}{ Higher Heating Values (MJ/kg) } \\
\cline { 2 - 4 } & Experimental & Predicted & Error \% \\
\hline RWC & 17.8 & 18.5 & 0.04 \\
\hline RWP & 17.4 & 18.2 & 0.04 \\
\hline UBC & 19.3 & 21 & 0.08 \\
\hline
\end{tabular}

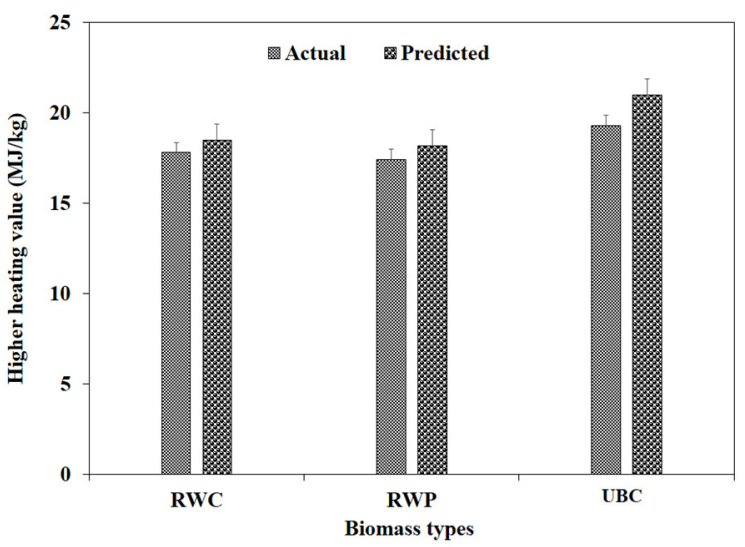

Fig. 3: Comparison of Measured HHV with HHV Estimates from Proximate Analysis

\subsubsection{Ultimate analysis based higher heating value}

Dulong equation and Boie equation are two common equations for determination of the higher heating value from ultimate analysis [26]. The Dulong equation is:

$\mathrm{HHV}(\mathrm{kJ} / \mathrm{kg})=0.34 \mathrm{C}+0.144(\mathrm{H}-\mathrm{O} / 8)+0.094 \mathrm{~S}$

and this is considered valid when the oxygen content of the biomass is less than $10 \%$. In the present case, however, the biomass samples have oxygen contents above $10 \%$. Hence, a formula for the gross heating value (HHV) of fossil fuels developed by Boie (1952) based on data for 16 biomass fuels, $66 \mathrm{coal} / \mathrm{coke} / \mathrm{char}$ fuels, and 67 oil fuels including alcohols, can be used. This empirical equation is:

$\mathrm{HHV}(\mathrm{kJ} / \mathrm{kg})=0.3516 \mathrm{C}+0.166225 \mathrm{H}-1.11+0.06280 \mathrm{~N}$ $+0.10465 \mathrm{~S}$

where $\mathrm{C}, \mathrm{H}, \mathrm{O}, \mathrm{N}$ and $\mathrm{S}$ refer to the mass fractions of the respective elements as determined by ultimate analysis. Oxygen has a negative coefficient because it reacts with some of the carbon and hydrogen to form $\mathrm{CO}, \mathrm{H}_{2} \mathrm{O}$, phenols $(\mathrm{OH})$ etc. [38]. Depending on the chemical functional groups of the fuels, the heating values may differ. The Boie equation gave much smaller differences between calculated and measured heating values than the Dulong equation. The measured and estimated HHVs for biomass samples are given in Tables 2 and 3, and graphs are shown in Figs. 3 and 4. The estimated HHV deviated from measured values by $0.04 \%$ to $0.15 \%$.

Table 3: Comparison of Measured HHV with Estimates from Ultimate Analysis

\begin{tabular}{|c|c|c|c|}
\hline \multirow{2}{*}{ Biomass } & \multicolumn{3}{|c|}{ Higher Heating Value (MJ/kg) } \\
\cline { 2 - 4 } & Experimental & Predicted & Error \% \\
\hline RWC & 17.8 & 18.7 & 0.05 \\
\hline RWP & 17.4 & 20 & 0.15 \\
\hline UBC & 19.3 & 21 & 0.08 \\
\hline
\end{tabular}

The unburned char showed HHV of $19.3 \mathrm{MJ} / \mathrm{kg}$, followed by rubber wood chips $(17.8 \mathrm{MJ} / \mathrm{kg}$ ) and rubber wood pellets $(17.4 \mathrm{MJ} / \mathrm{kg})$, as shown in Table (3). The experimental and predicted HHVs show that rubber wood biomass is relatively suitable for power generation via gasification and combustion. The heating values of rubber wood are higher than those of various woody biomasses, such as pile wood (stacked, $50 \%)(\mathrm{HHV}=9.5 \mathrm{MJ} / \mathrm{kg})$, industrial softwood chips with $50 \%$ moisture content $(\mathrm{HHV}=9.5 \mathrm{MJ} / \mathrm{kg}$ ), industrial softwood chips with $20 \%$ moisture content (HHV= $15.2 \mathrm{MJ} / \mathrm{kg}$ ), and forest soft wood with $20 \%$ moisture content $(\mathrm{HHV}=13.3 \mathrm{MJ} / \mathrm{kg}$ ). On the other hand, the HHVs of current samples are lower than those of commonly used fuels, such as gasoline $(\mathrm{HHV}=47.5 \mathrm{MJ} / \mathrm{kg})$, diesel $(\mathrm{HHV}=47 \mathrm{MJ} / \mathrm{kg})$, biodiesel $(\mathrm{HHV}=40 \mathrm{MJ} / \mathrm{kg})$, heavy fuel $(\mathrm{HHV}=43$ $\mathrm{MJ} / \mathrm{kg}$ ), natural gas $(\mathrm{HHV}=33 \mathrm{MJ} / \mathrm{kg})$, and coal $(\mathrm{HHV}=20.3 \mathrm{MJ} / \mathrm{kg}$ ). However, the experimental and 
estimated heating values of unburned char are closely similar to coal, and all three feedstocks showed better heating values than bituminous coal, brown coal (lignite) and peat (US department of energy). These are typical properties of biomasses suited for gasification [39]. The results show that the biomass feedstocks including rubber wood chips, rubber wood pellets and unburned char are suitable feedstocks for syngas production via gasification.

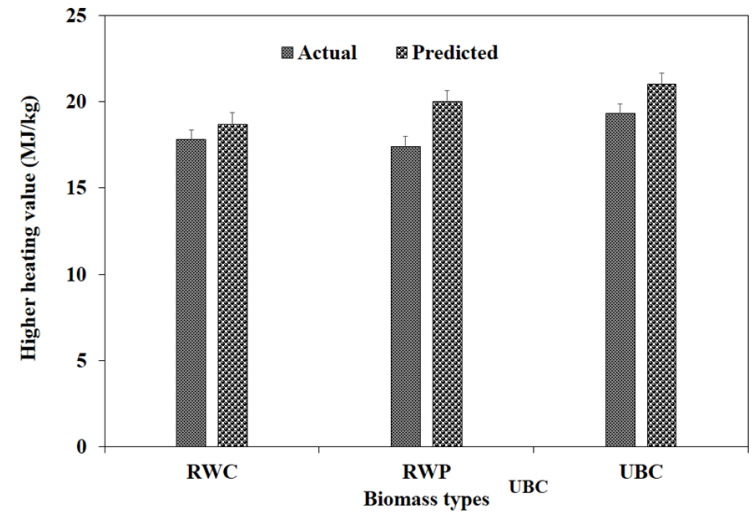

Fig. 4: Comparison of Estimated and Measured HHV, with Estimates based on Ultimate Analysis.

\subsubsection{Thermogravimetric analysis (TGA)}

Fig. 5 presents the TGA and DTG profiles of RWC, $\mathrm{RWP}$ and $\mathrm{UBC}$ for $10^{\circ} \mathrm{C} / \mathrm{min}$ heating rate. It is seen that there are four stages in the thermal decomposition of RWC and RWP, but not so for the UBC. The initial stage of degradation occurred at $100-120^{\circ} \mathrm{C}$, which is associated with evaporation of moisture. The second stage occurred at $120-250^{\circ} \mathrm{C}$. At this stage, the weight loss was relatively constant as the thermal energy supplied to biomass was used to increase its temperature. The third stage, was at $250-400{ }^{\circ} \mathrm{C}$, with the main loss of volatile matter from hemicellulose and cellulose. The last stage $\left(400-1000{ }^{\circ} \mathrm{C}\right)$ was slow degradation by decomposition of lignin. In the case of UBC, it is observed that the thermal decomposition occurred slowly. This is because the main component of UBC is lignin, as shown in Fig. 2. The RWC and RWP had high cellulose and hemicellulose contents that were more prone to thermal degradation than the UBC, whereas the unburned char contained lignin that was more stable and less volatile. The first observed weight loss was most probably from loss of hemicellulose and cellulose components [40]. The results are quite similar to previous studies about the thermal weight loss behavior of lignin [41].

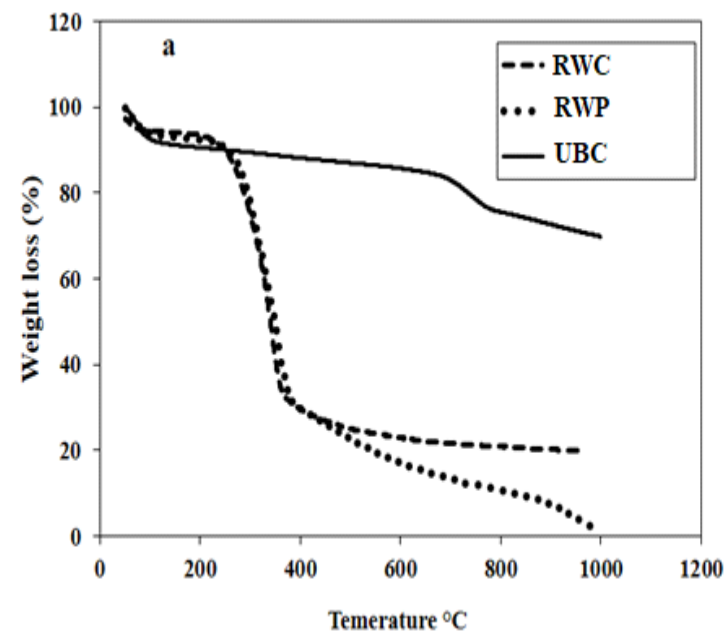

(a)

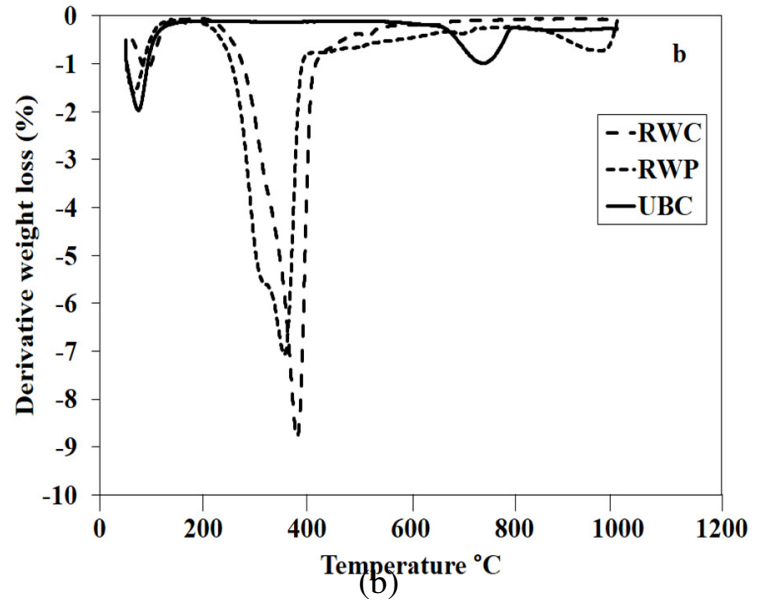

Fig. 5: TGA (a) and DTG (b) profiles of RWC, RWP and UBC

\subsection{Syngas composition and its heating value}

\subsubsection{Effect of biomass type on syngas composition}

The distribution of syngas components, including $\mathrm{CO}$, $\mathrm{CO}_{2}, \mathrm{H}_{2}$ and $\mathrm{CH}_{4}$, mainly depends on biomass feedstock and gasification operating conditions $[44,45]$. Different rubber wood biomasses and their blends were subjected to gasification at an equivalence ratio (ER) of 0.3. This ER was selected due to efficient performance of modified downdraft gasifier based on our preliminary evaluation.

The compositions of syngas samples are presented in Table 4 . The ranges of different syngas components were $\mathrm{CO}(10.81-22.67 \%), \mathrm{H}_{2}(7.62-13.45 \%), \mathrm{CH}_{4}$ Mehran University Research Journal of Engineering and Technology, Vol. 40, No. 1, January 2021 [p-ISSN: 0254-7821, e-ISSN: 2413-7219] 
(0.06-3.16\%), $\mathrm{CO}_{2}(9.875-18.28 \%)$ and $\mathrm{N}_{2}(50-60 \%$ determined by difference), and these are in agreement with previous studies on downdraft gasification [4648]. The high percentage of $\mathrm{CO}$ in syngas is substantially important for gas quality. It should be noted that single phase RWP yielded $8.72 \%$ and $6.12 \%$ more CO than RWC and UBC, and similar results were observed by Sarker and Nielsen (2015) while investigating wood biomass from birch, oak, spruce, poplar, and willow employing a downdraft gasifier. Moreover, $\mathrm{CH}_{4}$ and $\mathrm{CO}_{2}$ of RWP syngas are also high as compared to the other two single biomasses. However, its $\mathrm{H}_{2}$ content is $3.16 \%$ lower and $2.67 \%$ higher than UBC and RWC, respectively. This variation in syngas components is attributed to feedstock properties.

Interestingly, co-gasification of RWP or RWC with $50 \%$ UBC contained $\mathrm{CO}$ almost 1.5-2 fold more than gas from RWC and UBC, while only 2-3\% more than RWP. The fractions of other gas components from blended fuel, such as $\mathrm{CO}_{2}$ and $\mathrm{H}_{2}$, were $3-6 \%$ and $2 \%$ lower than in gas from RWP and UBC, while 1.15$1.62 \%$ and $2.3-3.6 \%$ higher than in gas from RWC (Table 4). In contrast, no significant difference in gas composition between the two blended feedstocks was observed. Relative abundance of carbon in syngas for all feedstocks indicates their suitability as fuel sources. The overall high carbon content in syngas is important for its heating value [49]. In case of UBC unavailability as a blending stock, RWP alone could be utilized, which already gives a good carbon content with high proportion of CO (19.57\%).

The effects of biomass feedstocks and their blends on the average syngas composition are given in Table 4 . The volumetric concentration of $\mathrm{CO}$ varied from 10.81 to 22.67 (Vol. \%) in syngas. The highest $\mathrm{CO}$ yield was 19.57 for RWP, which was further increased to 22.67 and 21.64 by introducing blends of RWP:UBC and RWC:UBC. Probably the reason for this improvement is that the RWC is not compacted by its nature, whereas RWP and UBC are very hard and tough, and these materials provides favorable conditions for reactions between carbon in the feedstock and air. It was difficult to evaluate the exact governing reactions in the gasification process; however, it is anticipated that the Boudouard reaction $\left(\mathrm{C}+\mathrm{CO}_{2} \rightarrow 2 \mathrm{CO}\right)$ was dominant, which resulted increased $\mathrm{CO}$ and reduced
$\mathrm{CO}_{2}$ in the syngas [50]. The effects of feedstock on the concentration of $\mathrm{H}_{2}$ can be seen in Table 4. The results indicate that the concentration of $\mathrm{H}_{2}$ ranges between 7.62 and 13.45 (vol. \%) in single and co-gasification. The $\mathrm{H}_{2}$ content increased gradually to maximally 13.45 (vol. \%) for UBC. This is $43.34 \%$ higher than in gasification of RWC only. RWP also shows a higher concentration of $\mathrm{H}_{2}$ in syngas than in gasification of the blends RWC:UBC and RWP:UBC. The possible reactions involved in hydrogen production during the co-gasification are the water gas primary reaction $(\mathrm{C}+$ $\left.\mathrm{H}_{2} \mathrm{O} \rightarrow \mathrm{CO}+\mathrm{H}_{2}\right)$ and the water-gas shift reaction $(\mathrm{CO}$ $+\mathrm{H}_{2} \mathrm{O} \rightarrow \mathrm{CO}_{2}+\mathrm{H}_{2}$ ). The impact of a high percentage of $\mathrm{CH}_{4}$ in syngas can be seen in terms of a higher HHV of syngas. It is shown in Table 4 that the concentration of $\mathrm{CH}_{4}$ varied between 0.06-3.16 (vol. \%) during single and co-gasification. The maximum value was for gasification of RWP, while the lower 0.06 (vol. \%) was observed for UBC. The second highest result on 1.61 (vol. \%) was obtained for $100 \%$ RWC. There was not much positive effects from the blending of feedstocks on the concentration of $\mathrm{CH}_{4}$. The concentration of $\mathrm{CO}_{2}$ in syngas was found to be in the range 9.87-18.28 (vol. \%), where the highest concentration was for RWP and the lowest was for RWC. In addition, lower concentrations of $\mathrm{CH}_{4}$ were observed for co-gasification of feedstock.

Overall, the co-gasification resulted in better quality of syngas than gasification of an individual biomass. Among the co-gasification results, blending of RWP and UBC was found to be the best alternative due to the high $\mathrm{H}_{2}$ and $\mathrm{CO}$ contents. The reason for good quality syngas from blended RWP:UBC may be the improved flow of air inside the gasifier due to packing of the particles, as compared to pure RWP or RWC gasification. Blending fibrous and light RWP or RWC with the denser hard UBC resulted in improved reactions in the gasifier, probably via improved airfuel interactions.

\subsubsection{Effects of biomass type on HHV of syngas}

The effects of biomass feedstock on the HHV of syngas from gasification or co-gasification are listed in Table 4. The heating value of the syngas was calculated from the average syngas composition (only combustible components) by considering $12 \mathrm{~kg}$ biomass batch, and using standard $\mathrm{HHV}$ [42] for $\mathrm{H}_{2}=$ 
$12.76 \mathrm{MJ} / \mathrm{m}^{3} ; \mathrm{CO}=12.63 \mathrm{MJ} / \mathrm{m}^{3}$ and $\mathrm{CH}_{4}=39.76$ $\mathrm{MJ} / \mathrm{m}^{3}$. It was assumed that $1 \mathrm{~kg}$ of biomass could be converted to $2 \mathrm{~m}^{3}$ of syngas. The heating value of syngas depends on its combustible components i.e. $\mathrm{CO}, \mathrm{H}_{2}$ and $\mathrm{CH}_{4}$ fractions. The composition of syngas and its component fractions could vary with feedstock, operating conditions and processing mode. A higher ER generally gives synthesis gas of lower heating value, partly due to dilution by $\mathrm{N}_{2}$ [43]. Amin et al. [24] reported that the heating value of gas obtained at ER 0.2 from coconut shell, mango pit shell and ginisyria had HHV $4.02 \mathrm{MJ} / \mathrm{m}^{3}, 3.29 \mathrm{MJ} / \mathrm{m}^{3}$ and 3.70 $\mathrm{MJ} / \mathrm{m}^{3}$, respectively [24]. Another study reported that at fixed air flow rate varying the ER in the range of $0.32-0.43$ resulted in higher synthesis gas yield and lower yield of ash and tar [43]. The optimum operating ER was 0.38 , for which the gas yield was $2.33 \mathrm{Nm}^{3}$ per kg of dry biomass with a heating value of 4.94 $\mathrm{MJ} / \mathrm{Nm}^{3}$.

$\Delta \mathrm{H}\left(\mathrm{MJ} / \mathrm{m}^{3}\right)=12.76 \mathrm{H}_{2}+12.63 \mathrm{CO}+39.76 \mathrm{CH}_{4}$

In Table 4 the HHV was the highest for RWP at 5.04 $\mathrm{MJ} / \mathrm{m}^{3}$, while the HHV from co-gasification of RWP mixed with UBC or RWC mixed with UBC gave the second and third highest results. Overall the results indicate that mixing UBC with RWC or RWP could be an excellent combination in terms of energy generation, as well as in making the process more economical and environmentally friendly. The making of such blend may also decrease the production of ash at the end. Moreover, the removal of dust and tar in a wet scrubber has improved the quality of syngas, which ultimately gives a good energy yield.

\begin{tabular}{|c|c|c|c|c|c|}
\hline \multicolumn{6}{|c|}{$\begin{array}{c}\text { Table 4: Lower and Higher Heating Values of } \\
\text { Syngas from Different Biomass Feedstocks } \\
\text { Biomass feedback }\end{array}$} \\
\hline $\begin{array}{c}\text { Gas } \\
\text { Components }\end{array}$ & RWC & RWP & UBC & $\begin{array}{l}\text { UBC+ } \\
\text { RWC }\end{array}$ & $\begin{array}{l}\text { UBC+ } \\
\text { RWP }\end{array}$ \\
\hline $\mathrm{H}_{2}$ & 7.9 & & & 8.07 & 8.74 \\
\hline $\mathrm{CH}_{4}$ & 1.6 & 3. & 0.06 & 0.68 & 1.27 \\
\hline $\mathrm{CO}$ & 10.8 & 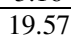 & 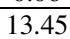 & 21.64 & 22.67 \\
\hline $\mathrm{CO}_{2}$ & 9.87 & 18.28 & 16.7 & 12.33 & $\begin{array}{l}13.46 \\
\end{array}$ \\
\hline $\begin{array}{c}\text { LHV } \\
\left(\mathrm{MJ} / \mathrm{m}^{3}\right)\end{array}$ & 2.78 & 4.72 & 3.17 & 4.27 & 3.85 \\
\hline $\begin{array}{c}\mathrm{HHV} \\
\left(\mathrm{MJ} / \mathrm{m}^{3}\right)\end{array}$ & 2.98 & 5.04 & 3.45 & 4.03 & $\begin{array}{l}4.48 \\
\end{array}$ \\
\hline
\end{tabular}

\subsubsection{Effect of Biomass type on LHV of Syngas}

The heating value of syngas is very important to the gas quality and its suitability for applications. The heating value of syngas has direct relation with the Carbon fraction in the gas components and can be determined by the following correlation [45]. The biomass type and gasification operating condition have a great influence on the syngas composition and its component fractions.

LHV $=\sum$ vol. \% of combustible components $\mathrm{x}$ LHV of combustible component

The LHV (MJ) of each combustible component that included $\mathrm{H}_{2}, \mathrm{CH}_{4}, \mathrm{CO}$, and $\mathrm{CO}_{2}$ is $10.783,35.883$, 12.683 and 0 , respectively. $\mathrm{N}_{2}$ acts as carrier gas during gasification and its heating value is zero as well. The LHV of syngas produced from different rubber wood feedstocks is shown in Fig. 6. It could be seen that RWP (4.72 MJ) gave greater LHV than RWC (2.78 MJ), UBC (3.17 MJ), blended RWC:UBC (3.85 MJ) or blended RWP:UBC (4.27 MJ). This was about 1.1 and 1.7 fold higher than the bounds of LHV range for investigated biomass samples. As discussed previously, a high carbon fraction gives a greater LHV for syngas, which is supported by our findings as well. It has been observed that blended fuel gives higher $\mathrm{CO}$ content than a single feedstock, but lower LHV than RWP. The greater heating value of RWP is due to higher concentration of $\mathrm{CH}_{4}$ (3.16\%) in syngas than with the other feedstocks tested in this study. It could be further noted that, as the heating value of combustible $\mathrm{CH}_{4}$ is larger than that of $\mathrm{CO}$, a feedstock generating more methane would have a greater heating value, as is observed for RWP in this work. Conclusively, to obtain syngas with a greater heating value for use in power generation, it must contain a sufficient fraction of $\mathrm{CH}_{4}$ as well in addition to a high $\mathrm{CO}$ concentration. The current study is in reasonable agreement with prior literature.

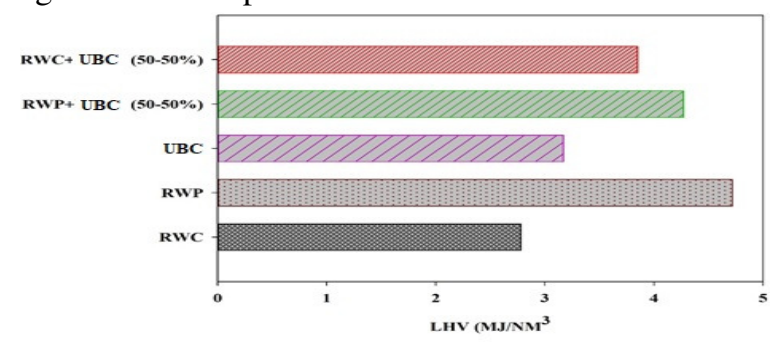

Fig. 6: Lower heating value $\left(\mathrm{MJ} / \mathrm{Nm}^{3}\right)$ of syngas produced from different biomass feedstocks. 


\subsection{Energy perspectives of rubber wood biomass with Thailand}

Rubber trees are economically among the most important trees in southeast Asia, south China, and west Africa. They are the only source of natural rubber, so the cultivation of rubber trees increases with the demand of natural rubber. Thus, the natural rubber producing industry in many countries supports the local farmers to establish rubber plantations to match the increasing demand [51]. Rubber trees are among the main cultivated plants in Thailand. The plantations cover 3-4 million hectares of the cultivated land (Fig. 7). Moreover, the latex production by rubber trees diminishes around 25 years of age, and newer genotypes of rubber plant have been developed with higher latex production compared to the old clonal varieties. Because of this, 25 years old trees are regularly felled and replaced with newer genotypes. In past history the old trees were burned, but nowadays the wood from these old trees is processed into lumber rather than burned, which is an environmentally friendly practice. Rubber wood is considered a medium hardwood with many promising characteristics. Furniture and cabinets, household woodenwares and parquet flooring are the main products from rubber wood. The furniture industry produces a large amount of wood residues as waste, and these are converted into RWC and RWP. Thailand has a planation area of more than three million hectares in the past 9 years (Fig. 7) and these produce enormous amounts of rubber wood biomass, specifically from the furniture industries. This biomass could significantly contribute to the energy sector in Thailand, if converted with sophisticated modern technologies such as biomass gasification.

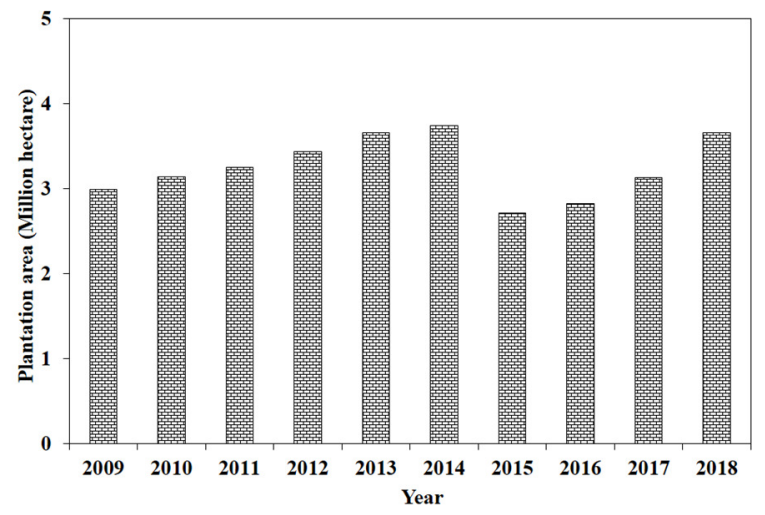

Fig. 7: Time profile of rubber tree plantation area in Thailand

Thailand is an agricultural country and produces a considerable amount of biomass from various agricultural products (Table 5). Even though a large amount of these feedstocks of biomass are locally employed in heat and energy generation, yet, interestingly, a considerable amount of these in terms of the equivalent energy ( $\mathrm{kWh} /$ year) are waste streams, as shown in Table 5 [52]. Natural rubber producing industry is a large industry sector in Thailand producing about one-third of the world's natural rubber [52], and southern Thailand has 2.7 million hectares of land with rubber plants of the total 3.5 million hectares of rubber plant cultivation.

Table 5: Potential of Biomass Sources in Thailand

\begin{tabular}{|c|c|l|c|c|}
\hline Biomass Type & $\begin{array}{c}\text { Total Biomass } \\
\text { (Tons/year) }\end{array}$ & $\begin{array}{c}\text { Spent Biomass } \\
\text { Tons/year) }\end{array}$ & Biomass Surplus & $\begin{array}{c}\text { Equivalent to } \\
\text { Energy } \\
\text { (tWh/year) }\end{array}$ \\
\hline Rice Straw & $10,727,682.14$ & $1,086,774.12$ & $9,640,908.02$ & 7.34 \\
\hline Rice Husk & $4,597,578.06$ & $3,680,679.20$ & $916,898.86$ & 3.45 \\
\hline Sugarcane leaves and tops & $7,810,955.43$ & $815,995.82$ & $6,994,959.61$ & 6.01 \\
\hline Bagasse & $7,644,639$ & $7,568,192$ & 76,447 & 3.13 \\
\hline Leaves and stems of corn & $956,876.34$ & $788,822.04$ & $168,054.30$ & 0.001 \\
\hline Corn cobs & $956,876.34$ & $788,822.04$ & $168,054.30$ & 0.511 \\
\hline Cassava roots & $4,171,526.33$ & Not used for energy & $4,171,526.33$ & 1.27 \\
\hline Palm trunk & $1,441,884.50$ & Not used for energy & $1,441,884.50$ & 0.60 \\
\hline Palm leaves and branches & $10,529,274.34$ & $326,451.31$ & $10,202,823.03$ & 1.02 \\
\hline Palm empty branch & $2,389,622.55$ & $1,417,539.37$ & 972,083 & 0.38 \\
\hline Rubber tree & $5,171,360$ & $1,311,509$ & $3,859,851$ & 1.61 \\
\hline
\end{tabular}

Mehran University Research Journal of Engineering and Technology, Vol. 40, No. 1, January 2021 [p-ISSN: 0254-7821, e-ISSN: 2413-7219] 
From an economic point of view regarding the next 25-30 years, replanting the rubber trees generates about 20 million tons of rubber wood, which is an important raw material in manufacturing wood products, such as furniture. Large amounts of residue are generated by this wood processing. Moreover, the $\mathrm{CO}_{2}$ emissions of wood chips and wood pellets are 10 times lower than of traditional fuel sources, as shown in Fig. 8. The low carbon emissions of rubber wood biomass are a feature of bioenergy feedstocks. Hence, the utilization of the residues as energy sources supports overcoming the energy challenges while environmentally friendly as well.

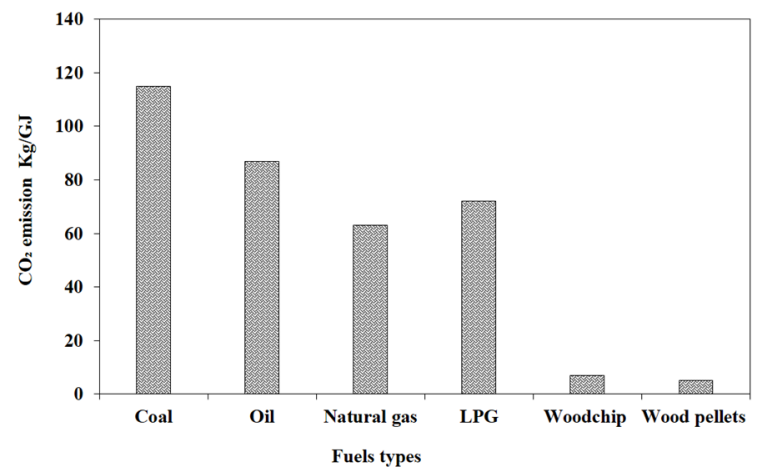

Fig. 8. $\mathrm{CO}_{2}$ emissions from various fossil fuels compared with the biomass feedstocks

The remaining residues, such as branches and wood slabs, are normally processed into wood chips, which are currently used as fuel in boilers to produce heat and steam or co-processed with coal in cement kilns. However, due to the naturally low bulk density and low heating value, biomass utilization in the existing combustion processes designed for fossil fuels normally encounters some technical limitations. The fraction of biomass in a co-combustion system is normally kept at a low level, to maintain the desired system efficiency [53].

The current study was an effort to address the above mentioned problem; different rubber wood biomasses were subjected into modified downdraft gasifier for syngas production. The results revealed that rubber wood in pellet form is more suitable for maximum energy recovery in terms of heating value of the syngas. Modified gasification system performance was successfully demonstrated for single phase and blended biomass feedstocks. It is worth noting that the system performed very well with a high 50:50 blend ratio of RWP:UBC, and produced gas with $4.75 \mathrm{MJ}$ heating value.

\section{CONCLUSIONS}

This study investigated the physiochemical properties of rubber wood biomasses and their potential for synthesis gas production in a downdraft gasifier. The investigated biomass types were rubber wood chips (RWC), rubber wood pellets (RWP), unburned char (UBC) from rubber wood, RWC mixed with UBC (50:50), and RWP mixed with UBC (50:50). The physiochemical properties, namely bulk density, proximate analysis, ultimate analysis, lignocellulose content, heating value and TGA were assessed for the alternative biomass types. The syngas production in a downdraft gasifier had ER fixed at 0.3. The results indicate that RWC and RWP had high volatile matter contents (74.4-75.4\%), whereas the UBC showed the highest $50.6 \%$ fixed carbon content. The UBC also had high carbon (58.54\%) and low oxygen contents (14.81\%). The higher heating value of UBC was 19.3 $\mathrm{MJ} / \mathrm{kg}$ which was the highest among the cases tested. The dominant chemical component of UBC was lignin $(63 \%)$. A comparison of the estimated and measured HHV of biomass samples showed that the Boie's equation gave fairly accurate estimates. The properties revealed that the investigated biomass can be used for energy via gasification. The gasification results showed that the co-fuel mixes of RWP with UBC or RWC with UBC provided improved LHV (3.85-4.27 $\mathrm{MJ} / \mathrm{m}^{3}$ ). The distribution of syngas components, including $\mathrm{CO}, \mathrm{CO}_{2}, \mathrm{H}_{2}$ and $\mathrm{CH}_{4}$ in the syngas, mainly depended on biomass feedstock. These results facilitate using rubber wood biomass for heat and power generation via gasification in Thailand.

\section{REFERENCES}

[1] Ellabban O., Abu-rub H., and Blaabjerg F., "Renewable energy resources : Current status, future prospects and their enabling technology," Renewable and Sustainable Energy Reviews, Vol. 39, pp. 748-764, 2014.

[2] Saleem L., Ulfat I., On R., On A., "A Multi Criteria Approach to Rank Renewable Energy Technologies for Domestic Sector Electricity Demand of Pakistan," Mehran University Research. Journal of Engineering and 
Technology, Vol. 38, No. 2, pp. 443-452, 2019.

[3] BP, "Statistical Review of World Energy, 2018 ", 2018.

[4] Vassilev S.V., Baxter D., Andersen L. K., Vassileva C. G., Morgan T. J., "An overview of the organic and inorganic phase composition of biomass", Fuel, Vol. 94. pp. 133, 2012.

[5] IRENA, Renewable Energy Outlook: Thailand. 2017.

[6] Srirangan K., Akawi L., Moo-young M., Chou C. P., "Towards sustainable production of clean energy carriers from biomass resources," Applied Energy, Vol. 100, pp. 172-186, 2012.

[7] Anwar Z., Gulfraz M., Irshad M., "Agroindustrial lignocellulosic biomass a key to unlock the future bio-energy: A brief review," Journal of Radiation Research and Applied Sciences, Vol. 7, No. 2, pp. 163-173, 2014.

[8] Yokoyama S. Y., Ogi T., and Nalampoon A., "Biomass energy potential in Thailand," Biomass and Bioenergy, Vol. 18, No. 5, pp. 405-410, 2000.

[9] Romyen A., Sausue P., Charenjiratragul S., "Investigation of rubber-based intercropping system in Southern Thailand", Kasetsart Journal of Social Sciences., Vol. 39, No. 1, pp. 135-142, 2018.

[10] Ratnasingam J., Ramasamy G., Wai L.T., Senin A.L., Muttiah N., "The prospects of Rubber wood biomass industry in Malaysia", BioResources, Vol 10, No.2, pp. 2526-2548, 2015.

[11] Akdeniz F., Biçil M., Karadede Y., Özbek F. E., Özdemir G., "Application of real valued genetic algorithm on prediction of higher heating values of various lignocellulosic materials using lignin and extractive contents", Energy, Vol. 160, pp. 1047-1054, 2018.

[12] Yu Z. T., Xu X., Hu Y. C., Fan L. W., and Cen K. F., "Unsteady natural convection heat transfer from a heated horizontal circular cylinder to its air-filled coaxial triangular enclosure", Fuel, Vol. 90, No. 3, pp. 11281132, 2011.
[13] Chen W., Annamalai K., Ansley R. J., Mirik M., "Updraft fixed bed gasification of mesquite and juniper wood samples", Energy, Vol. 41, No. 1, pp. 454-461, 2012.

[14] Amin M., Wickramaarachchi W. A. M. K. P., Narayana M., "Performance analysis of updraft gasifier", Proceedings of the International Conference on Sustainable Energy Engineering and Application (ICSEEA), 2016, No. 1, pp. 61-65., 2016.

[15] Fernando N., Amin M., Narayana M., Jayawickrama T., Asadullah, Jayasena S., "A mathematical model for Pyrolysis of biomass", Proceedings of the Moratuwa Engineering Research Conference, 2015.

[16] Adams P., Bridgwater T., Lea-Langton A., Ross A., Watson I., "Biomass Conversion Technologies. Report to NNFCC.," Greenhouse Gas Balances of Bioenergy Systems, pp. 107-139. 2017.

[17] Unep, "Global Mercury Assessment 2013: Sources, Emissions, Releases, and Environmental Transport”, Unep, p. 42, 2013.

[18] Amin M., Chetpattananondh P., Ratanawilai S., "Application of extracted marine Chlorella sp. residue for bio-oil production as the biomass feedstock and microwave absorber," Energy Conversion and Management, Vol. 195, pp. 819-829, 2019.

[19] Amin M., Narayana M., Asadullah, Kamran Sami S., Khan M. N., Sultan S. H., "Bioenergy production from waste mango seed shell by thermo-chemical conversion and its importance for mango fruit processing industry", Journal of Applied and Emerging Sciences, Vol. 9, No. 1, pp. 48-52, 2019.

[20] Watson J., Zhang Y., Si B., Chen W. T., de Souza R., "Gasification of biowaste: A critical review and outlooks", Renewable and Sustainable Energy Reviews, Vol. 83. pp. 117, 2018.

[21] Maitlo G., Mahar R. B., Bhatti Z. A., and Unar I. N., "A Comprehensive Literature Review of Thermochemical Conversion of Biomass for Syngas Production and Associated Challenges", Mehran University Research Journal of Engineeing and Technology", Vol. 38, No. 2, pp. 495-512, 2019. 
33[22] Ueki Y., Torigoe T., Ono H., Yoshiie R., Kihedu J. H., Naruse I., "Gasification characteristics of woody biomass in the packed bed reactor", Proceedings of the Combustion Institute., Vol. 33, No. 2, pp. 1795-1800, 2011.

[23] Gunarathne D., "Optimization of the performance of down-draft biomass gasifier installed at National Engineering Research \& Development ( NERD ) Centre of Sri Lanka", pp. 1-51, 2012.

[24] Amin M., Narayna M., "Comparative Study of Energy Potential of Mango Pit As Biomass With Coconut Shell Ginisyria \& Mixture In Laboratory Scale Developed Updraft Gasifier", Rsea, Vol. 2015, pp. 299-302, 2015.

[25] Goering H. K., Van Soest P. J., Forage fiber analysis (apparatus, reagents, procedures, and some applications), Agricultural Research Service, U.S. Dept. of Agriculture, Washington, D.C., 1970.

[26] Annamalai K., Sweeten J. M., and Ramalingam S.C., "Technical Notes: Estimation of Gross Heating Values of Biomass Fuels", Transactions of the ASAE, Vol. 30, No. 4, pp. 1205-1208, 1987.

[27] Sheng C., Azevedo J. L. T., "Estimating the higher heating value of biomass fuels from basic analysis data", Biomass and Bioenergy, Vol. 28, No. 5, pp. 499-507, 2005.

[28] Demirbaş A., "Biomass resource facilities and biomass conversion processing for fuels and chemicals", Energy Conversion and Management, Vol. 42, No. 11, pp. 1357-1378, 2001.

[29] Bharadwaj A., Baxter L.L., Robinson A. L., "Effects of intraparticle heat and mass transfer on biomass devolatilization: Experimental results and model predictions", Energy and Fuels, Vol. 18, No. 4, pp. 1021-1031, 2004.

[30] Palniandy L. K., Yoon L. W., Wong W. Y., Yong S. T., Pang M. M., "Application of Biochar derived from different types of biomass and treatment methods as a fuel source for direct carbon fuel cells", Energies, Vol. 12, No. 13, 2019.

[31] Haykiri-Acma H., Yaman S., Kucukbayrak S.,
"Gasification of biomass chars in steamnitrogen mixture," Energy Conversion and Management, Vol. 47, No. 7-8, pp. 10041013, 2006.

[32] Kumar A., Jones D. D., Hanna M. A., "Thermochemical biomass gasification: A review of the current status of the technology", Energies, Vol. 2, No. 3. pp. 556-581, 2009.

[33] Jahirul M. I., Rasul M. G., Chowdhury A. A., and Ashwath N., "Biofuels production through biomass pyrolysis- A technological review," Energies, Vol. 5, No. 12. pp. 49525001, 2012.

[34] Shen J., Zhu S., Liu X., Zhang H., Tan J., "The prediction of elemental composition of biomass based on proximate analysis", Energy Conversion and Management, Vol. 51, No. 5, pp. 983-987, 2010.

[35] Cordero T., Marquez F., Rodriguez-Mirasol J., Rodriguez J., "Predicting heating values of lignocellulosics and carbonaceous materials from proximate analysis," Fuel, Vol. 80, No. 11, pp. 1567-1571, 2001.

[36] Channiwala S. A., Parikh P. P., "A unified correlation for estimating HHV of solid, liquid and gaseous fuels", Fuel, Vol. 81, No. 8, pp. 1051-1063, 2002.

[37] Mierzwa-Hersztek M., Gondek K., Jewiarz M., Dziedzic K., "Assessment of energy parameters of biomass and biochars, leachability of heavy metals and phytotoxicity of their ashes," Journal of Material Cycles and Waste Management, Vol. 21, No. 4, pp. 786800, 2019.

[38] Stone R., Introduction to Internal Combustion Engines, Sae International, 1992.

[39] Wilson L., Yang W., Blasiak W., John G. R., and Mhilu C. F., "Thermal characterization of tropical biomass feedstocks", Energy Conversion and Managment, Vol. 52, No. 1, pp. 191-198, 2011.

[40] Muthuraman M., Namioka T., Yoshikawa K., "A comparison of co-combustion characteristics of coal with wood and hydrothermally treated municipal solid waste," Bioresource Technoology., Vol. 101, No. 7, pp. 2477-2482, 2010.

[41] Fan M., Brown R. C., "Comparison of the 
loss-on-ignition and thermogravimetric analysis techniques in measuring unburned carbon in coal fly ash," Energy and Fuels, Vol. 15, No. 6, pp. 1414-1417, 2001.

[42] Waldheim T., Nilsson L., "Heating Value of Gases from Report Prepared for: IEA Bioenergy Agreement”, English, May, 2001.

[43] Kaewluan S., Pipatmanomai S., "Gasification of high moisture rubber woodchip with rubber waste in a bubbling fluidized bed," Fuel Processing Technology, Vol. 92, No. 3, pp. 671-677, 2011.

[44] Ramchandriya K.D., Kundiyana D.K., Sharma A.M., Kumar A., Atiyeh H.K, Huhnke R.L., Wilkins M.R., "Critical factors affecting the integration of biomass gasification and syngas fermentation technology". AIMS Bioeng., Vol. 3, No. 2, pp. 188-210, 2016.

[45] Basu P., "Biomass Gasification, Pyrolysis and Torrefaction: Practical Design and Theory”, 2013.

[46] Simone M., Barontini F., Nicolella C., Tognotti L., "Gasification of pelletized biomass in a pilot scale downdraft gasifier," Bioresource Technology, Vol. 116, pp. 403412, 2012.

[47] Son Y. Il., Yoon S. J., Kim Y. K., Lee J. G., "Gasification and power generation characteristics of woody biomass utilizing a downdraft gasifier", Biomass and Bioenergy, Vol. 35, No. 10, pp. 4215-4220, 2011.

[48] Sarker S., Nielsen H. K., "Assessing the gasification potential of five woodchips species by employing a lab-scale fixed-bed downdraft reactor", Energy Conversion and Management, Vol. 103, pp. 801-813, 2015.

[49] Hassen A.B., Ghrib A., Zaafouri K., Friaa A., Querghi A., Naoui S., Belayouni H., "Hydrogen-Rich Syngas Production from Gasification and Pyrolysis of Solar Dried Sewage Sludge: Experimental and Modeling Investigations", Biomed Research Intionational, 2017.

[50] Inayat M., Sulaiman S. A., Sanaullah K., "Effect of blending ratio on co-gasification performance of tropical plant-based biomass", Proceedings of the $4^{\text {th }}$ IET Clean Energy and Technology Conference, 2016.
[51] Bhumiratana A., Intarapuk A., SorosjindaNunthawarasilp P., Maneekan P., Koyadun S., "Border malaria associated with multidrug resistance on Thailand-Myanmar and Thailand-Cambodia borders: Transmission dynamic, vulnerability, and surveillance," BioMed Research International, 2013.

[52] Krukanont P., Prasertsan S., "Geographical distribution of biomass and potential sites of rubber wood fired power plants in Southern Thailand," Biomass and Bioenergy, Vol. 26, No. 1, pp. 47-59, 2004.

[53] Kaewluan S., Pipatmanomai S., "Potential of synthesis gas production from rubber wood chip gasification in a bubbling fluidised bed gasifier", Energy Conversion and Management, Vol. 52, No. 1, pp. 75-84, 2011. 